\title{
Analisis Penerapan Pendidikan Karakter Pada Pembelajaran Tematik dalam Kurikulum 2013
}

\author{
Septi Wahyu Utami ${ }^{*}$, Asep Ardiyanto ${ }^{2}$, Arfilia Wijayanti ${ }^{3}$ \\ 1,2,3 PGSD Fakultas Ilmu Pendidikan Universitas PGRI Semarang
}

\section{A R T I C L E I N F O}

Article history:

Received 20 May 2019

Received in revised form 10 June 2019

Accepted 30 July 2019

Available online 28

August 2019

Kata Kunci:

Pendidikan Karakter,

Pembelajaran Tematik,

Kurikulum 2013

Keywords:

Character Education,

Thematic Learning, 2013

Curriculum

\begin{abstract}
A B S T R A K
Penelitian ini dilatarbelakangi oleh kondisi siswa yang nakal kepada temannya dan suka melakukan bullying, padahal di sekolah tersebut telah menerapkan pendidikan karakter melalui proses pembelajaran maupun non pembelajaran, bertujuan untuk mendeskripsikan bagaimana penerapan pendidikan karakter pada pembelajaran tematik dalam kurikulum 2013 siswa kelas 3A SDN Gayamsari 01 Semarang. penelitian ini difokuskan pada pembelajaran tematik tema 7 sub tema 1 dan 2 . Metode penelitian yang digunakan adalah penelitian kualitatif, teknik pengumpulan data yang digunakan meliputi wawancara, observasi, dokumentasi dan angket, menggunakan uji keabsahan data triangulasi. Hasil penelitian menunjukkan bahwa penerapan pendidikan karakter dalam pembelajaran tematik berjalan dengan baik, siswa sudah mampu menerapkan nilai-nilai karakter yang diajarkan, walaupun belum sepenuhnya, data presentase hasil penelitian meliputi presentase nilai karakter di RPP mencapai 38,88\%, presentase penerapan nilai karakter mencapai $55,55 \%$, presentase hasil observasi siswa mencapai 84, $375 \%$, dan presentase hasil angket mencapai 100 $\%$.
\end{abstract}

\section{A B S T R A C T}

This research is motivated by the condition of students who are naughty to their friends and like to do bullying, even though the school has implemented character education through learning and non-learning processes, aimed at describing how the application of character education in thematic learning in the 2013 curriculum of 3 th grade students at Gayamsari Elementary School 01 Semarang. This study focused on thematic learning themes 7 sub themes 1 and 2. The research method used was qualitative research, data collection techniques used included interviews, observation, documentation and questionnaires, using the validity test of triangulation data. The results showed that the application of character education in thematic learning went well, students were able to apply character values that were taught, although not yet fully, the percentage data of research results included the percentage of character values in the lesson plan reaching $38.88 \%$, the percentage application of character values reached $55.55 \%$, the percentage of student observations reached 84 , $375 \%$, and the percentage of questionnaire results reached $100 \%$. 


\section{Pendahuluan}

Pendidikan memiliki peran yang sangat penting dalam membentuk kualitas suatu bangsa. Sistem pendidikan nasional diharapkan harus mampu menjamin peningkatan mutu dan efisiensi manajemen pendidikan untuk menghadapi tantangan sesuai dengan tuntutan perubahan kehidupan di era global sehingga perlu dilakukan pembaharuan pendidikan secara terencana, terarah, dan berkesinambungan. Pendidikan merupakan suatu faktor utama yang menentukan kualitas suatu bangsa. Pendidikan selalu menuntut adanya suatu perbaikan yang bersifat terus menerus. Oleh karena itu pembaharuan selalu dilakukan untuk meningkatkan kualitas pendidikan nasional.

Dalam Undang-Undang No. 20 Tahun 2003 pasal 1 ayat I tahun 2003 tentang sistem pendidikan nasional, dinyatakan:

Pendidikan adalah usaha sadar dan terencana untuk mewujudkan suasana belajar dan proses belajar agar peserta didik secara aktif membangun potensi dirinya untuk memiliki kekuatan spiritual keagamaan, pengendalian diri, kepribadian, kecerdasan, akhlak mulia, serta keterampilan yang diperlukan dirinya, masyarakat, bangsa dan negara.

Sementara itu, di dalam kebijakan nasional, antara lain ditegaskan bahwa pembangunan karakter bangsa merupakan kebutuhan asasi dalam proses berbangsa dan bernegara. Sejak awal kemerdekaan, bangsa indonesia sudah bertekad untuk menjadikan pembangunan karakter bangsa sebagai bahan penting dan tidak dapat dipisahkan dari pembangunan nasional. Lebih lanjut harus diingat bahwa secara eksplisit pendidikan karakter (watak) adalah amanat Undang-Undang Nomor 23 Tahun 2003 tentang sistem pendidikan nasional yang pada pasal 3 menegaskan bahwa:

Pendidikan nasional berfungsi mengembangkan kemampuan dan membentuk watak serta peradaban bangsa yang bermartabat dalam rangka mencerdaskan kehidupan bangsa, bertujuan untuk berkembangnya potensi peserta didik agar menjadi manusia yang beriman dan bertakwa kepada Tuhan Yang Maha Esa, berakhlak mulia, sehat, berilmu, cakap, kreatif, mandiri, dan menjadi warga negara yang demokratis serta bertanggung jawab.

Dalam dunia pendidikan saat ini banyak ditemukan berbagai permasalahan, salah satunya adalah permasalahan karakter para siswa, hal ini menandakan bahwa moral para siswa yang semakin memburuk. Moral para siswa sekarang ini mengalami penurunan yang sangat memprihatinkan, hal ini karena adanya arus globalisasi yang semakin hari semakin pesat. Dengan adanya arus globalisasi ini banyak sekali dampak buruk yang mengakibatkan moral para siswa generasi sekarang merosot drastis. Oleh karena itu pendidikan karakter ini sangat penting diterapkan dalam pendidikan di indonesia untuk mengatasi penurunan moral yang dialami para siwa di generasi sekarang ini. Seorang siswa tidak cukup hanya dibekali materi pembelajaran saja melainkan juga harus dibekali oleh pendidikan karakter yang baik, yang tentunya agar berguna bagi kehidupannya kelak untuk menjadi individu yang berkarakter baik. Pendidikan karakter sebaiknya diberikan seiring dengan perkembangan intelektualnya, hal ini berarti pendidikan karakter harus ditanamkan sejak dini yang pertama kali diberikan oleh keluarga.

Lickona 2004 dalam (Muslich, 2011:44) mendefinisikan bahwa pendidikan karakter sebagai upaya yang dirancang secara sengaja untuk memperbaiki karakter para siswa. Pendidikan karakter ini tidak hanya diperoleh dari lingkungan keluarga saja melainkan sekolah juga berhak dalam melaksanakan pendidikan karakter bagi siswa siswanya. Dengan adanya pendidikan karakter di sekolah maka akan dapat membantu pembentukan kepribadian yang baik dalam diri siswa. Pendidikan karakter di sekolah sangat diperlukan, walaupun dasar dari pendidikan karakter adalah di dalam keluarga. Kalau seorang anak mendapatkan pendidikan karakter yang baik dari keluarganya, anak tersebut akan berkarakter baik pada tahap selanjutnya. Namun banyak orang tua yang lebih mementingkan aspek kecerdasan otak ketimbang pendidikan karakter. Selain itu Daniel Goleman dalam (Muslich, 2011:30) mengatakan bahwa banyak orang tua yang gagal dalam mendidik karakter anak-anaknya baik karena kesibukan maupun karena lebih mementingkan aspek kognitif anak. Meskipun demikian, kondisi ini dapat ditanggulangi dengan memberikan pendidikan karakter di sekolah. Pendidikan karakter di sekolah dapat terapkan dalam proses pembelajaran hai ini akan selaras dengan pengembangan intelektual juga pengembangan karakter yang baik, sehingga melalui pembelajaran yang menerapkan pendidikan karakter akan dapat membantu siswa memiliki karakter yang baik dalam dirinya sendiri.

Pendidikan karakter sangat penting diterapkan. Hal ini sesuai dengan pendapat Lickona bahwa ada tujuh alasan mengapa pendidikan karakter itu harus disampaikan yaitu : (1) Cara terbaik untuk menjamin anak -anak (siswa) memiliki kepribadian yang baik dalam kehidupannya. (2) Cara untuk meningkatkan prestasi akademik. (3) Sebagian siswa tidak dapat membentuk karakter yang kuat bagi dirinya sendiri di tempat lain. (4) Mempersiapkan siswa untuk menghormati pihak lain atau orang lain dan dapat hidup dalam masyarakat yang beragam. (5) Berangkat dari akar masalah yang berkaitan 
dengan masalah moral - sosial, seperti ketidaksopanan, ketidakjujuran, kekerasan, pelanggaran kegiatan seksual, dan etos kerja (belajar) yang rendah. (6) Sebagai persiapan terbaik untuk menyongsong perilaku di tempat kerja. (7) Mengajarkan akan nilai-nilai budaya merupakan bagian dari kerja peradaban.

Berdasarkan Penelitian yang dilakukan oleh Siti Julaiha. Dalam jurnal penelitian Dinamika Ilmu Vol. 14. No 2, Desember 2014 yang berjudul "Implementasi Pendidikan Karakter dalam Pembelajaran". Dalam penelitian ini Institusi pendidikan menjadi tempat sentral untuk menciptakan generasi muda yang lebih baik dari pada orang-orang pribadi melalui pendidikan karakter. Pendidikan karakter adalah proses menciptakan siswa menjadi manusia yang sangat baik dalam dimensi pikiran, cara berpikir, sehat secara fisik, dan hati manusia. Pendidikan karakter mengukir ahlaq siswa melalui proses mengetahui yang baik, mencintai yang baik, dan bertindak baik. Proses itu melibatkan aspek koqnitif, emosional, dan fisik, sehingga ahlaq yang mulia bisa ukiran menjadi kebiasaan pikiran, hati, dan tangan. Pendidikan karakter diarahkan untuk menciptakan yang tangguh, kompetitif, berhati mulia, bermoral, toleran, membantu, patriotik, dan dinamis orang yang memiliki orientasi ilmu dan pengetahuan berdasarkan keyakinan dan kesalehan Allah SWT. Seorang guru menerapkan pendidikan karakter dalam proses belajar mengajar oleh membuat siswa merumuskan pertanyaan secara aktif, menemukan sumber belajar, mengumpulkan informasi, bekerja dengan informasi, merekonstruksi fakta, dan menyajikan hasil rekonstruksi. Pembelajaran pendidikan karakter harus dilakukan oleh para guru dari perencanaan, implementasi, dan evaluasi.

Berdasarkan pengamatan yang dilakukan peneliti selama kegiatan magang 3 di SDN Gayamsari 01 Semarang. Bahwa di sekolah tersebut ada beberapa masalah pendidikan yang ada, salah satunya yaitu permasalahan karakter para siswa, hal ini dilihat dari siswa yang nakal dan suka melakukan bullying sesama siswa, hal ini diketahui peneliti dengan melakukan tanya jawab kepada salah seorang siswa bahwa sebagian besar temannya nakal kepada sesama temannya, nakal tersebut berkaitan dengan katrakter siswa sehingga dapat dikatakan bahwa karakter para siswa sebagian besar masih mengalami masalah. Untuk mengatasi masalah ini diketahui bahwa di sekolah tersebut telah menerapkan pendidikan karakter di sekolah melalui proses pembelajaran maupun non pembelajaran walaupun sekolah tersebut belum diakui sebagai SD PPK. Melalui proses pembelajaran di setiap kelas telah menggunakan kurikulum 2013 dan setiap pembelajarannya ada nilai karakter yang telah ditentukan untuk diajarkan, sehingga setiap pembelajaran akan menerapkan pendidikan karakter yang baik untuk para siswa. Untuk kegiatan non pembelajaran misalnya melalui kegiatan pembiasaan kegiatan yang berhubungan dengan pembentukkan karakter siswa misalnya Upacara, Sholat Berjamaah, Jabat tangan dengan guru dan lainlain. Dengan adanya kegiatan ini diharapkan akan dapat membantu siswa dalam pembentukkan karakternya menjadi lebih baik lagi. Untuk itu peneliti ingin meneliti mengenai "analisis penerapan pendidikan karakter pada pembelajaran tematik dalam kurikulum 2013 siswa kelas 3a sdn gayamsari 01 semarang". Penelitian ini bertujuan untuk mendeskripsikan penerapan pendidikan karakter pada pembelajaran tematik kelas 3A SDN Gayamsari 01 Semarang.

\section{Metode}

Dalam penelitian ini peneliti menggunakan penelitian deskriptif dengan pendekatan kualitatif. Data dalam penelitian ini berupa data kualitatif, yaitu data dengan menggunakan kata-kata atau pendeskripsian mengenai fakta atau fenomena yang sedang diamati. Sumber Data dalam penelitian ini dapat berupa data primer. Data primer adalah yaitu sumber data yang langsung memberikan data kepada pengumpul data. Dalam penelitian kualitatif, yang menjadi instrumen atau alat penelitian adalah peneliti itu sendiri, dengan sunyek penelitian adalah siswa kelas 3A SDN Gayamsari 01 Semarang. Prosedur pengumpulan data yang dilakukan dalam penelitian ini menggunakan beberapa cara agar data yang diperoleh merupakan data yang valid dan kredibel mengenai penelitian ini. Dalam penelitian ini teknik pengumpulan data yang digunakan meliputi wawancara, observasi, dokumentasi dan angket. Penelitian ini dilaksanakan di SDN Gayamsari 01 Semarang. SDN Gayamsari 01 semarang beralamat di Jl. Beruang Raya No. 01 Semarang 50161. Penelitian ini dilaksanakan antara bulan Desember 2018 - Mei 2019. Dalam penelitian ini digunakan uji keabsahan data uji credibility (validitas internal). Uji credibility yang digunakan adalah dengan menggunakan triangulasi. Metode analisis data yang digunakan dalam penelitian ini adalah metode analisis data selama di lapangan model Miles and Huberman. Analisis data dalam penelitian ini dilakukan pada saat pengumpulan data berlangsung, dan setelah selesai pengumpulan data dalam periode tertentu. 


\section{Hasil dan Pembahasan}

Berdasarkan hasil temuan yang telah dilakukan oleh peneliti selama melakukan penelitian di SDN Gayamsari 01 Semarang bahwa penerapan pendidikan karakter di sekolah ini telah dilaksanakan secara rutin selama 1 tahun ini yaitu di mulai dari tahun 2018, sebenarnya kegiatan ini sudah sejak lama dilaksanakan tetapi belum berjalan dengan rutin. Kegiatan ini dilatarbelakangi oleh adanya tuntutan dari kurikulum dan agar kedepannya para siswa memiliki nilai-nilai karakter yang sesuai dengan budaya bangsa. Proses penerapan pendidikan karakter di sekolah ini dilaksanakan melalui kegiatan pembelajaran di kelas dan kegiatan ekstrakurikuler.

Untuk kegiatan pembelajaran di dalam kelas dilaksanakan dengan menerapkan pembelajaran tematik dalam penerapan pendidikan karakter di sekolah ini. penerapan pendidikan karakter melalui proses pembelajaran tematik di kelas sudah berlangsung secara baik, siswa sudah dapat menerima nilainilai karakter yang diterapkan guru walaupun belum sepenuhnya dapat diterapkan. Nilai-nilai yang sudah dapat diterapkan siswa secara rutin adalah religius, gotong royong, toleransi, kerjasama, disiplin, dan tanggung jawab. Nilai-nilai yang diterapkan guru setiap pembelajaran sebelumnya sudah dicantumkan dalam perangkat pembelajaran yang telah dibuat. Kendala yang dialami guru adalah ketika siswa kurang fokus dalam menerapakan nilai karakter dalam proses pembelajaran. Untuk penerapan melalui kegiatan ekstrakurikuler dilaksanakan melalui kegiatan pramuka, ekstrakurikuler, dan rebana. (ekstrakurikuler yang ada di sekolah). Penerapan kegiatan ini berjalan dengan baik, pihak sekolah tidak merasa ada hambatan karena yang penting kegiatan ini dapat berjalan dengan baik secara rutin.

Sebelum guru melaksanakan pembelajaran tematik dengan menerapkan pendidikan karakter, guru terlebih dahulu harus membuat RPP yang sudah mencantumkan nilai karakter. Nilai karakter yang muncul pada RPP pembelajaran tematik kelas 3 tema 7 subtema 1 dan 2 adalah Religius, Toleransi, Disiplin, Mandiri, Demokratis, Bersahabat/ Komunikatif, Peduli lingkungan, Cinta Tanah Air, Gemar membaca. Jadi ada 10 dari 18 nilai karakter yang ada dalam RPP pembelajaran tematik tema 7 sub tema 1 dan 2. Dengan presentase nilai karakter yang ada di RPP mencapai 38,88 \%. Selanjutnya nilai karakter yang dicantumkan dalam RPP disesuaikan dengan proses pembelajaran yang dilaksanakan guru di dalam kelas. Nilai karakter yang dicantumkan pada RPP pembelajaran tematik kelas 3 tema 7 subtema 1 dan 2 telah diterapkan semuanya dengan baik, dan dalam setiap pembelajaran yang berlangsung ada beberapa nilai karakter yang diterapkan walaupun tidak tercantumkan dalam RPP, presentase penerapan nilai karakter mencapai $55,55 \%$.

Dalam proses pembelajaran yang dilaksanakan guru di dalam kelas peneliti melakukan observasi kepada siswa untuk mengetahui nilai karakter yang dimiliki oleh siswa di kelas, dari observasi ini diketahui bahawa nilai karakter yang belum sepenuhnya dimiliki siswa di dalam kelas setiap harinya adalah nilai karakter Kreatif, dan Semangat kebangsaan. Nilai kretaif belum dimiliki siswa dalam hal ini dilihat dari kegiatan siswa yang hanya meniru dan mengikuti guru saja, belum ada ide - ide yang muncul dalam dirinya sehingga nilai karakter ini belum sepenuhnya di miliki oleh siswa di dalam kelas. Nilai semangat kebangsaan belum dimiliki siswa dalam hal ini dilihat dari kegiatan sebelum pembelajaran yang mengharuskan adanya apel pagi di depan kelas dan menyanyikan lagu Indonesia Raya, akan tetapi kegiatan ini tidak dilaksanakan setiap harinya oleh siswa siswa sehingga nilai ini belum sepenuhnya dimiliki oleh siswa di kelas, dan juga ada beberapa nilai karakter yang munculnya tidak tetap dalam setiap pembelajaran nilai karakter tersebut adalah demokratis, rasa ingin tahu, bersahabat, gemar membaca, dan cinta damai. Presentase hasil observasi pada siswa mencapai 84, $375 \%$.

Sedangkan dari hasil angket siswa diketahui bahwa nilai karakter yang dimiliki oleh siswa setiap harinya berbeda dari siswa satu dengan siswa lainnya. Nilai karakter yang selalu dimiliki oleh siswa di kelas adalah nilai Religius, Toleransi, Disiplin, Kerja keras, Mandiri, Demokratis, Semangat kebangsaan, Cinta tanah air, Gemar membaca, dan Tanggung jawab. Presentase hasil angket mencapai $100 \%$.

Proses penerapan pendidikan karakterdi SDN Gayamsari 01 Semarang selama ini sudah berjalan dengan baik, hal ini bisa dilihat dari perubahan nilai karakter yang dimiliki oleh siswa yang selalu berubah ke arah yang lebih baik, kegiatan ini dapat berjalan dengan baik karena adanya kontribusi yang baik dari pihak sekolah dan siswa. Proses penerapan pendidikan karakter melalui pembelajaran tematik diharapkan dapat membantu siswa dalam perbaikan nilai karakter dalam dirinya, seperti yang diketahui bahwa nilai karakter siswa siswa di kelas ini masih kurang sehingga dengan adanya penerapan pendidikan karakter pada pembelajaran tematik akan membantu siswa menjadi pribadi yang lebih baik lagi. 


\section{Simpulan Dan Saran}

Berdasarkan hasil penelitian yang telah dilakukan maka dapat disimpulkan bahwa Kegiatan penerapan pendidikan karakter di SDN Gayamsari 01 Semarang dilaksanakan melalui kegiatan Ekstrakurikuler dan proses pembelajaran di kelas. Penerapan pendidikan karakter di dalam kelas dilaksanakan dengan pembelajaran tematik sesuai dengan kurikulum 2013, dimana nilai-nilai karakter yang akan diterapkan sebelumnya sudah dicantumkan dalam RPP. Penerapan nilai karakter melalui pembelajaran tematik tidak selalu sesuai dengan RPP, artinya ada nilai karakter lain yang diterapkan guru di dalam kelas walaupun tidak dicantumkan dalam RPP. Nilai karakter yang selalu dimiliki siswa dalam satu hari pembelajaran dalam sub tema 1 dan 2 tema 7 adalah Nilai Religius, Toleransi, Disiplin, Kerja keras, Mandiri, Demokratis, Semangat kebangsaan, Cinta tanah air, Gemar membaca, dan Tanggung jaawab. Proses penerapan pendidikan karakter di SDN Gayamsari 01 Semarang selama ini sudah berjalan dengan baik, hal ini dapat dilihat dari perubahan nilai karakter yang dimiliki oleh siswa yang selalu berubah ke arah yang lebih baik

\section{Daftar Rujukan}

Akhwan, Muzoffar. 2014. Pendidikan Karakter: Konsep dan Implementasinya Dalam Pembelajaran di Sekolah/Madrasah. El-Tarbawi Vol. 7 No.1 2014

Daryanto, S. D. 2013. Implementasi Pendidikan Karakter di Sekolah. Yogyakarta: Gava Media.

Daryanto. 2014. Pembelajaran Tematik, Terpadu, Terintegrasi (Kurikulum 2013). Yogyakarta:Gava Media.

Fadlillah, M. 2014. Implementasi Kurikulum 2013 Dalam Pembelajaran SD/MI, SMP/MTS \& SMA/MA. Yogyakarta: Ar-Ruzz Media.

Julaiha, Siti. 2014. Implementasi Pendidikan Karakter Dalam Pembelajaran. Dinamika Ilmu Vol. 14. No 2, Desember 2014

Kadir, Abd. 2014. Pembelajaran Tematik. Jakarta:PT Raja Grafindo Persada.

Koesoema, A. Doni. 2007. Pendidikan Karakter; Strategi Mendidik Anak di zaman Global. Jakarta: Grasindo.

Ma'unah. Dalam. Analisis pendidikan karakter pada pembelajaran matematika dalam kurikulum tingkat satuan pendidikan (Siswa Kelas VIII B dan VIII C SMP Muhammadiyah 10 Surakarta Tahun 2013/2014. Naskah publikasi FKIP UMS.

Mulyasa, M. 2011. Manajemen Pendidikan Karakter. Jakarta: Bumi Aksara.

Muslich, M. 2011. Pendidikan Karakter Menjawab Tantangan Krisis Multidimensional. Jakarta: PT Bumi Aksara.

Samani, D. H. 2011. Konsep dan Model Pendidikan Karakter. Bandung : PT

Remaja Rosdakarya.

Soegeng A.Y. Ysh., M. 2015. Etika Pancasila Nilai - Nilai Pembentuk Karakter.

Yogyakarta: Magnum Pustaka Utama .

Soegeng A.Y. Ysh., M. 2016. Filsafat Pendidikan . Yogyakarta: Magnum Pustaka Utama.

Soegeng A. Y. Ysh., M. D. 2016. Landasan Pendidikan Karakter. Yogyakarta: $\quad$ Magnum Pustaka Utama. 
Sugiyono, P. D. 2014. Metode Penelitian Pendidikan Pendekatan Kuantitatif,Kualitatif, dan R\&D. Bandung: Alfabeta.

Susiyanto Mukti Widiya. 2014. Analisis implementasi pendidikan karakter di sekolah dalam rangka pembentukan sikap disiplin siswa. Jurnal Pendidikan Ekonomi IKIP Veteran Semarang. Vol. 2 No. 1, November 2014. 